\title{
RURAL RECREATION, A SOCIALIZING FACTOR
}

\author{
By Myron T. Scudder, \\ Professor of the Science of Education in Rutgers College.
}

In April, 1906, a few men and women interested in play met in Washington, D. C., and organized the Playground Association of America. The little group was received at the White House by President Roosevelt, who later consented to become honorary president of the infant organization. Dr. Luther Halsey Gulick was made president.

Thus launched, the association grew with amazing rapidity and at the end of the first year, when a great playground congress was held in Chicago, it was realized that one of the most profoundly significant social and educational movements of modern times was taking shape, and had already become powerful and effective.

And this development has gone on with ever accelerating momentum until now every state in the Union is reached by its propaganda. A splendid literature on play has developed, and since unlooked-for ramifications and extensions of the play propaganda have appeared as the movement progressed, carefully selected committees have explored, charted, studied and described these, their reports having been published in the bulky proceedings of the playground association.

In the meantime the name of the association itself has been broadened to include all that the newer conception of the playground idea stands for, and has been changed to the "Playground and Recreation Association of America," its headquarters being in the Metropolitan Building in New York, where a strong official force is maintained, while field secretaries are busy the country over responding to calls for help.

Playgrounds and recreation centers, organized in the interests of adults as well as of children, are appearing everywhere, out of doors, in buildings, on roofs, in asylums, hospitals, factories, and even within prison yards. It has been discovered that play is not only a means of happiness, but is essential as a means of normal physical development, as a means of intellectual, moral and social 
education. In many institutions it is found to have therapeutic uses for the healing of disease, as well as for breaking tup the monotonous routine of institutional life. It is quite natural that most of this activity has been confined to our cities, first, because nearly all the promoters were city people, and, second, because it had not been realized, perhaps we may say suspected, that country people as well as city people needed supervised recreation and play. Yet we find in these days that the rural population also is coming to its own, and that a very vigorous extension of the play propaganda is reaching even into the country. What its purpose, methods and outcome are we must now proceed to describe, or rather hint at, for in the limited space allotted to this article nothing but a short resumé of the subject can be given.

The United States census designates as rural all who live outside of cities of 8,000 or more in population. In common use, however, it has a much narrower significance, and for the purposes of the present discussion we shall limit it to the little villages, crossroad communities, camps, and scattered populations, seaboard and inland, which have to do with the developing and marketing of the natural resources of the country. Suburban communities and large villages are not rural. It is a pity that the word rural is not better comprehended, for looseness in its use leads to looseness in thought and to error in inference and in conclusion. No one can grasp the real meaning of the word who has not lived in the country and absorbed the psychology of the truly rural mind. Socially and psychologically the native of the open country is different from the urbanite. One may live in the country for years and not get the rural feeling and the rural point of view. To own a farm or a house in the country does not necessarily make the owner rural. He may never fully grasp the significance of rural life. If he is city bred, he probably never will. He will be in the country but not of it.

Now the truly rural mind as developed on the farm is greater than the urban mind. It is almost purely democratic. In it, labor and capital are reconciled, and the farmer sees no reason why he and his hired help should not eat as well as work side by side in shirtsleeves. In it the psychology of manufacturing, buying, selling, storing and transporting, operate in harmony in one mind instead of at cross purposes in many minds as in the city. In it 
the professional, the scientific, and the mercantile must strike a fairly even balance. The fully developed rural mind, the product of its environment, is more original, more versatile, more accurate, more philosophical, more practical, more persevering than the urban mind; it is a larger, freer mind and dominates tremendously.

It is because of this type of farm bred mind that our leaders have largely come from rural life. Ninety-four per cent of the leading citizens of one of our large Eastern cities, according to Dr. Hillis, of Brooklyn, were brought up on the farm. Of a group of one hundred representative men, commercial and professional, in Chicago, it was found that eighty-five per cent were farm or village bred. Eighty-five per cent of the students in four colleges and seminaries came from country districts, while upwards of sixty per cent of the men and women mentioned in Who's Who likewise are from the country. Dr. Hillis well says: "The brain and nerve centers are not more dependent upon the soundness of the related tissues than the city upon the rural districts."

And it is, of course, essential to national welfare that the rural districts should continue to furnish such leaders and therefore should be populous, prosperous, and contented. Yet everyone knows that they are neither the one nor the other. Isolation, hard work, long hours and small returns have increased discontent especially amongst the young, while the call of the city has been increasingly seductive. So it is not to be wondered at that a natural, legitimate migration from country to town has swelled to alarming proportions, scores of thousands fleeing like fugitives from the hardships and isolation of the farm lands, their departure making still more dreary and deadening to those who remain behind, the isolation from which they had escaped, and augmenting a discontent that in many sections has caused people to settle down into an almost helpless lethargy. The uppermost sentiment nearly every where seems to be: "Any thing but this! How can I get away?" National welfare requires that this point of view be changed to one in which, with cheery hopefulness, all ask: "How can we make conditions such that we shall be glad to stay?"

At this point it is important to bear in mind that the terms "rural" and "country" mean very different things in different sections. A statement that is entirely applicable to a farming section or to country villages in, say, the mountain regions of eastern Ten- 
nessee, or perhaps nearer home, should not be considered as "personal" by residents of the many cultured, rural communities of which this nation is so justly proud. Stop a moment to consider the varied rural communities of this land of ours. Think of the mountain whites and the Georgia "crackers," think of the sparsely settled population of the Far West, of the rude mining settlements and lumber districts, perhaps fifty miles from any railroad, think of the black belt of the South, the half-civilized Indians, the undesirable immigrants, and others who are dispersed over our agricultural districts East, West, North and South, some perhaps nearer than we like, and remember that these are part and parcel of the rural problem.

In many rural communities conditions are thoroughly disheartening. Something must be done for them. With schools and churches, feeble, extinct, or unheard of, no worse places could be conceived of in which to bring up children. No wonder people want to leave. Yet for the sake of our national welfare they must be made wholesome.

Now, while a complete and frank description of such rural conditions as may be found in many parts of all of our states would make a dark picture, yet with it all one would have to tell of many communities of refinement and great prosperity, and of many measures of relief and promises of better days. A rural renaissance has already dawned. Better methods of agriculture and of business co-operation will relieve the industrial and economic elements of the situation, while an awakening church, an improved school, and a richer and more inspiring community life will tend to make social conditions centripetal instead of centrifugal and lessen the suffering from isolation.

It is in this latter respect that the recreation and playground idea will make itself felt, and it is hardly putting it too strongly to say that a well planned propaganda of recreation is as vital a necessity to the country's welfare as is improved farming.

Country people need more recreation and they need to be trained in the art of recreation and amusement. The older people everywhere give but little thought to the recreational side of life, while with certain elements of the population the quest for means of passing leisure hours often takes crude, uninteresting and even childish forms, not infrequently is rough and grotesque, and 
altogether too commonly leads to immorality to a degree that is not generally suspected.

Into this matter of promoting wholesome recreation for the young and old the rural church, the reconstructed school, sometimes consolidated but more frequently under one teacher, the rural Y. M. C. A., the grange, and other fraternal orders, must enter heart and soul. As the writer has pointed out elsewhere, an adequate program of play would include pleasurable outdoor and indoor occupation, for (a) day schools, (b) homes, (c) Sunday schools, (d) other social organizations, public and private, suitable for Sundays as well as week-days, adjusted to the season of the year, and adapted to the needs of (I) very little children, (2) children from eight to thirteen, (3) boys and girls in the adolescent period, (4) adults; sex as well as age being taken into account when necessary. The word play thus broadened brings us into the realms of kindergartens, manual training departments, vacation schools, summer camps, boys' clubs, girls' clubs, nature-study clubs, camera clubs, collection clubs; it has to do with swimming, fishing, boating, skating, skeeing, and snow-shoeing; also with all forms of athletics; with the use of tools and implements, with the use of clay, plasticine, paper pulp, and putty for modeling; with the use of tops and marbles, bean-bags, balls and kites, stilts, toys, soap bubbles, cards, dissected maps, scrap books, and the myriad other amusement materials, plays and games which are the heritage of the human race, and without sharing in which no child can grow to complete manhood or womanhood, and no adult can live a cheerful, joyous, well-rounded-out life.

Let us itemize with brief comment or description some of the more important phases of a propaganda for socialized, supervised recreation, indoors and outdoors, in home, church, school, and community. Of course, we can do no more than hastily glance at the possibilities, with the hope of opening up the field in a suggestive way.

I. Amongst other indoor activities we should emphasize story telling. Mr. Richard T. Wyche, so well known as an apostle of this great and important art, says, "There are many homes that cannot afford libraries and the rich adornment of art, but no home is so humble that parents cannot gather the children around the fireside on a winter's evening or about the doorsteps in the twilight of a 
summer's day and tell them stories." This is an art that parents and many other adults should cultivate. And note Mr. Wyche's suggestion about the fireside. The open fireplace can work social wonders if people will only give it a chance! Suggestive lists of books on story telling may be obtained of the Playground and Recreation Association of America.

2. From the story told at the fireside to the story told on a stage or platform before an audience is a natural evolution. Dramatic societies should be organized in every good sized community, and where the population is scattered several communities may unite to form one. We are only beginning to sense the educational value of dramatization. Yet once it was the best if not the only way to spread great truths amongst the people, as, for instance, the teaching of Biblical events and characters by the mystery and miracle plays of the middle ages. Note the results of an active village dramatic society in Oberammergau, Germany. Largely through its influence there has developed the most remarkable community in all this world, a little village in a remote mountain district, which generation after generation continues to produce gifted men, superb women and beautiful, wonderfully beautiful, and clever children, in extraordinary numbers. Oberammergau cannot be duplicated elsewhere perhaps, yet properly conducted dramatics will greatly enrich life in our country communities, as it has there.

3. Clubs for boys and girls are as necessary in the country as in the city. Besides clubs covering particular interests like photography, nature-study, Bible study, etc., organizations like the Boy Scouts, Campfire Girls, Knights of King Arthur and Pioneer Girls should be fostered and supervised by adults. Here is where the country pastor may exert a powerful influence, as well as the country teacher.

4. The grange and other fraternal orders, fire companies, literary and library associations furnish club life for men and women, and in these the recreation idea may well be emphasized. To such organizations the children must appeal for sympathy and help in their playground propaganda. A woman's club in a certain village gave a giant stride to the children. Its example is worthy of emulation.

5. Promoted by these organizations, communities should maintain lecture and entertainment courses, reading circles, a public 
library, and, where possible, a choral union. Then there is the stereopticon with its wonderful possibilities. No community or group of communities should be without one, and systematic provision for its use should be made. The old fashioned husking bees and barn raisings are things of the past in all but a few communities, but why not bring back the spelling match and the singing school? Those of us who were brought up on such things know what an important part they played in our lives.

6. Church, school and other socials should pay more intelligent attention to their programs of recreation. Social evenings frequently are uninteresting, insipid and foolish because not carefully planned. They disgust and alienate instead of proving attractive and inspiring. On such occasions there may well be a serious core to the evening, a short literary and musical program, for instance, or a club meeting to discuss matters of community interest, to be preceded and followed by plenty of fun and amusement. Well thought out programs of entertainment, fun and recreation for all sorts of gatherings in the country are greatly needed.

7. Township or county gatherings, extending perhaps through two or three days, have been successfully maintained in several states. Most famous of these is the Hesperia movement, a winter gathering of Michigan farmers and teachers which has met for years in Hesperia, miles from any railway, to enjoy a program of lectures, music and discussion from Thursday night to Saturday night. Mr. D. E. McClure, to whom most of the credit for this movement must be given, said once, "Thousands of people have been inspired, made better, at the Hesperia meetings." Hesperia, with its powerful appeal to the craving for wholesome recreation, certainly has induced many to stay on their farms. It is a signal instance of the efficacy of a properly conducted "Stay on the Farm Movement," which is far more important than the "Back to the Farm Movement."

8. Itinerant social and literary meetings have also proved a success. Assembling by strawload or by walking parties on a given Saturday, bringing their lunch and meeting in a school house, church or village hall, people from several communities may gather with great profit and pleasure several times a year.

9. Systematic effort should be made to teach plays and games to children and to instruct them in the art of framing up programs 
of indoor amusement. Such books as Bancroft's "Games for the Playground, Home, School and Gymnasium," the Dan Beard Handy Books, Nugent's "New Games and Amusements" and Johnson's "Education by Plays and Games" should be owned by every school and church, and constantly used. Country children do not play enough because they do not know enough about play. Their repertoire of games is exceeding limited, and their elders are even worse off than they are. Hence the importance of systematic effort to teach them what and how to play. The splendid work being done in this direction by some of the Y. M. C. A. county work secretaries, who actually have gone from one country school to another to ask permission to teach the children a few new games, is worthy of emulation.

Io. Manual training, industrial and domestic arts, and naturestudy furnish much indoor occupation which has high recreational value. The making of collections (stamps, autographs, eggs, etc.) should be encouraged, so should the making of useful articles for the home or school. Manual methods in Sunday school work are also decidedly in point here.

II. What has so far been said suggests the importance of having, in connection with church, school and home, a definite storeroom or place for play and recreation materials, which should be treated with the same dignity as a library and should be as liberally maintained as possible. In it would be kept not only the toys and games, but materials for constructing various articles, drawing and painting materials, costumes that have been used in dramatics and that will surely come in handy again some day, pictures, projection apparatus, etc.

Outdoor recreation and play for country communities may include ( $\mathrm{I}$ ) activities suggested by the environment itself, such as hunting, fishing, camping, tramping, mountain climbing, water sports, winter sports, certain phases of nature-study and of farm work, like sugar making, husking bees, and so on; (2) group activities for boys like the Boy Scouts, and for girls like the Campfire Girls; (3) regular playground activities with organized and supervised plays, games and athletics; (4) community activities, such as pageants and festivals, county fairs and athletic field days and play picnics. Of these:

I. Hunting and fishing cannot figure conspicuously in the long 
settled sections of the country for the obvious reason that fish and game are scarce. When these sports are no longer available, other forms of recreation must be provided to take their place, though not with the expectation that they will be as effective. The old-fashioned husking bee is no more, but the sugar bush is still with us, though in less romantic form because of its modern methods. It is now very business like and is no longer the "recreation center" it used to be in numberless places, with its rude shelter, its kettles, sap buckets and roaring campfires.

To supplement, or to take the place of these old time recreations, the more modern forms of camping out may well be encouraged in the country. Who has not known of boys putting up a tent near the house, or making a rough shelter in the woods and sleeping and eating in it for days at a time? Here is an instinct of which country pastors and teachers may well take advantage. A few tents in a community, owned by the church perhaps, or by the grange, or even by a ladies' club, may be made a means of grace to many if under the supervision of a wise leader.

2. Tramping is an almost unknown, or at least unpracticed, form of recreation in America, though it is popular in Europe. Pile some bedding into a wagon with provisions and extra clothing, and, with an objective point two or three days away, such as some historic site, some college of agriculture, some mountain, city or body of water, let the trampers set forth properly supervised and guided, camping along the road and thoroughly enjoying an outing whose retrospect is only less delightful than the actual experience, especially if cameras are taken along to make a visual record of current events.

3. Mountain climbing is another pastime which is just beginning to be appreciated in this country, but chiefly by city people. Tens of thousands of our rural population live near superb mountains, the conquest of which by climbing will prove most inspiring to mountaineering clubs whose membership should include women and girls. Recent magazine articles show the possibilities of this sport.

4. What has been called the "caravan" gives an interesting outing. It is a train of wagons, fitted up as comfortably and as attractively as may be desired, a la gypsy style, one serving as a parlor, another as a kitchen, others as sleeping rooms, and so on, 
the caravan moving leisurely through the country in a most comfortable outing.

5. For the water there is the houseboat, with a great variety of possibilities, perhaps too expensive for a single family, but feasible for co-operative effort, especially if fitted up in the simple inexpensive way practiced by fishermen and river boatmen.

Tramping and camping expeditions may be accompanied by programs of plays and games, athletic events and water sports to any extent desired, with appropriate badges and mementos for excellence shown in competition or in attaining certain standards. Indeed, some outings are rendered onerous and dull for lack of the incidental play which should be counted on to liven up the day's doings and prevent monotony.

6. The Boy Scouts and Campfire Girls should be organized in country districts as well as in cities, possibly with slightly different standards and tests. "Rural Scouts" have already appeared in the West, and perhaps this name instead of "Boy Scouts" should be adopted for country boys. Country girls have not been organized along these lines, although an organization of "Pioneer Girls" has been projected. But in the Tomato Clubs of the South girls have achieved an organization which, at the same time that it is professedly vocational, lends itself to social recreation to any desired extent. The same is true of the Corn Clubs and other similar organizations of country boys. Yet these vocational clubs, strongly recreational as they may be, cannot play that rich part in the social development of adolescents as do the Boy Scouts and Campfire Girls.

So far we have touched on the more informal modes of recreation, the equipment for which is the world about us in which man and nature are playmates. We now come to that still greater and perhaps more important, certainly more social, field of recreation, in which man plays with man, combining for purposes of recreation in numberless forms of activity which, when properly organized and supervised, develop efficiency, build character, and often fuse discordant elements into a homogeneous, co-operating mass. In this more specialized field the recreational activities center at the playground, and here play comes to be recognized as one of the most serious and important concerns of life.

One of the best things ever said about play comes from Mr. 
Joseph Lee, whom we delight to honor as the father of the modern playground movement in this country. "The thing that most needs to be understood about play," he says, "is that it is not a luxury, but a necessity; it is not something that a child likes to have; it is something that he must have if he is to grow up. It is more than an essential part of his education; it is an essential part of the law of his growth, of the process by which he becomes a man at all." All this is as true for the country child as for the city child.

But we must take a still wider view of outdoor play, and regard it as an essential for adults as well as for children. We should never get too old to play, and since it is so universally important we must undertake seriously to provide adequate play and recreation facilities for all. Having caught the wider significance of the playground idea, we shall come to recognize that the organized and supervised playground is as much a social institution as are the church and school.

And I would here emphasize, as I have in previous articles, that play in the country is not so much to promote health as to develop the higher social instincts, to introduce another powerful centripetal factor into country life which will tend to counteract the expulsive features which have been so actively depopulating our rural districts. A very important result of play in the country is the development of community spirit which is so seriously lacking in country districts. There seems to be so little to hold the people together. But once interest children in play, get them to organize teams, design and make a good school banner, compose and learn a school cheer, adopt a distinctive athletic costume or even a celluloid button which is to be worn when they go to the next great play festival and compete with other schools, and there will be no lack of community spirit so far as the children are concerned, and the adult population will soon be catching something of it too.

In country places playgrounds will have to come, if they come at all, through the generosity of some individual or clubs or on the initiative of some organization like a powerful school or college, a wide-awake church or a county work department of the Y. M. C. A. And they are actually coming in considerable numbers and in all parts of the country, and everywhere they produce the same social results. That is, they bring about fine community spirit, awaken civic consciousness and co-operation, and make for a whole-souled 
companionship instead of for individualism and isolation. If we could see the playground idea prevail throughout the rural communities of the land, the gain to the nation through the ever increasing number of cheerful, contented, industrious, patriotic citizens will be far greater than if mines of fabulous wealth were uncovered or all the commerce of the world were brought under our flag.

Regular, supervised play should begin at the home, and how fortunate the children who have parents who are in sympathy with play and who will occasionally find time to play with their children! Sand pile, swings and other inexpensive apparatus are easily provided, and so are the chinning bar, jumping pit and running course.

The same is true at the school, even the one-room school. Helpful literature is now available for those who are willing to take up this work. The country road will have to be pressed into service for some of the activities, but every school should have ample grounds laid out and equipped for such games as volley ball, badminton, prisoner's base, captain ball, baseball or playground ball (the latter requiring much less space than the former), relay races, etc. Marbles and kite flying should be encouraged, and so should red rover, leapfrog, duck on the rock, moving statues, and a hundred other games that are readily learned.

Folk dancing should be revived in the country as it has been in the city. Here again manuals of instruction are ready.

Teachers, pastors and play leaders should make use of excursions, picnics and camping expeditions, as suggested above.

National holidays and other special occasions may be observed by the holding of pageants. There is already a generous literature on this subject which may be obtained through the Playground and Recreation Association of America. The pageant idea for country communities has been worked out by Mr. W. C. Langdon at Thetford, Vermont. His pamphlet, "The Pageant of Thetford," is a classic in the literature of recreation.

An essential phase of playground activity is athletics. These cannot be elaborate, of course, and if the teacher feels unequal to the task perhaps the country pastor or some other adult in the community would help.

A beginning in athletics is usually made by having the boys run, jump and chin themselves in accordance with certain directions and standards as explained in the following blank, a badge or button being given to each boy who attains the required standards: 
ATHLETIC BADGE COMPETITION

Country School Athletic League,..............

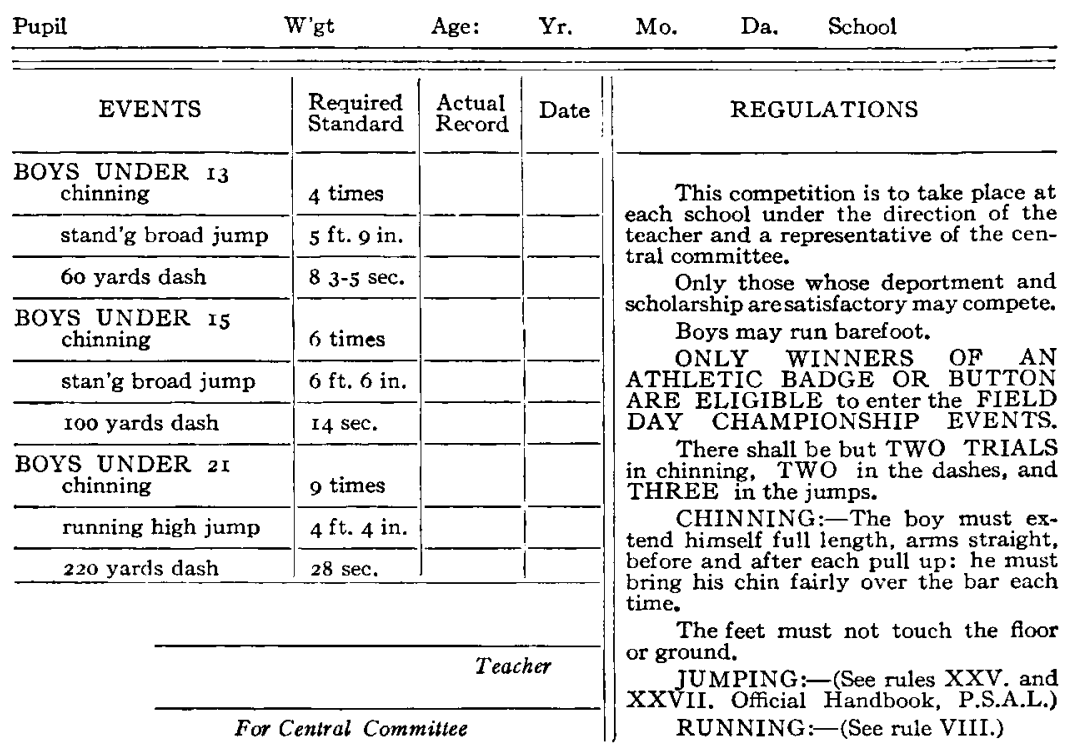

The most important factor in promoting play in the country is the field day and play picnic, the great day of the year when the country schools of the district or county meet at some central point and pass the day in play. Since the first field day of this sort was started by the writer of this paper in a little village in New York State some seven years ago, the idea has spread very generally through the country, and it may be said that the field day and play picnic has become an important rural institution. Its main features are as follows:

A country school athletic league is organized among the schools of a county or commissioners' district to foster all kinds of clean athletics among country children, to teach them and their teachers outdoor and indoor games, and to bring the schools together at least once a year in a great field day and play picnic. For purposes of instruction, circular letters giving lists of books on games and athletics and other important particulars are sent to all teachers and pastors, while a number of games like prisoner's base, captain ball and some relay races are published with illustrative cuts in village papers and sent broadcast through the county. To further 
aid the play propaganda volunteers are sent to the country schools to teach games and to help with the local athletic and badge contests. The matter is also presented at granges, institutes and public meetings by aid of the stereopticon.

Individual schools are encouraged to organize relay teams, and teams to play prisoner's base, baseball and other group games, and to compete with other schools. Individual schools are encouraged to have their own field days, while groups of three or four schools are urged to have an annual meet.

The grounds for the play festival, large enough to accommodate several thousand people, are portioned off into several play areas. In one place there are courts for prisoner's base, captain ball, bean-bag toss, basket-ball throw, and so on; another area is set aside for baseball or playground ball; still another is devoted to giant strides, playground slides, merry-go-rounds, and swings; nets are also stretched for volley ball, tennis and badminton, pits are dug for jumping, courses marked out for running and racing, a range laid out for archery, and many an interesting game or contrivance for testing skill or otherwise affording amusement is at hand here and there to attract little groups of children, who wander about all day long in perfect delight from one interesting occupation to another.

Provision is made for checking the packages and lunches of the thousands of guests, while water and toilet accommodations must be carefully and generously planned. Tents must be set up for those who are to sell frankfurters, sandwiches, ice cream and soft drinks.

An important feature of the occasion is the day nursery, consisting of one or more tents, furnished with cots, kindergarten tables and play materials, a sand pile just outside the door, and appropriate eatables which may well include sterilized milk in bottles for the infants. Here mothers may check their babies free of charge, leaving them in competent care while they themselves spend the hours in joyous freedom.

Carefully prepared programs are printed and freely distributed and trained play leaders are at hand to teach children and adults how to play and to supervise the activities of the day.

Balloon ascensions and other imported amusements and spectacles are strictly excluded, for this is a day of play of the people, 
by the people and for the people. Thousands come to these occasions, and we want these thousands to play and not merely to be amused by hired performers.

\section{Quoting from a recent article by the writer of this paper:}

It is well worth while to stand at a place of vantage and watch these thousands assemble from every direction intent upon play, some by train, many on foot and horselack, and hundreds by wagon, caravans of which wind their way from neighboring villages and farms. Sometimes an entire district school comes to town on a hay-wagon, with flags and banners flying and with its school cheer frequently in evidence. Just think for a moment what this means to that school. It shows that co-operation, fellow-feeling, school spirit, community loyalty, and kindred virtues have been born into their lives, and that perhaps for the first time in their experience the social forces of country life have become centripetal and attractive instead of centrifugal and expulsive.

It should be emphasized that a play festival is not just for fun; it is not merely to while away leisure time; it is not a mere picnic. The latter has its value and is not to be decried, but it usually grows out of no special purpose other than to have a pleasing outing, and it exercises no permanent influence. The play festival, on the other hand, like the ancient festivals and feast days which are made familiar to us through the Bible, is of purposeful intent and has an important mission to perform. Of course, it consists largely of play, and one of its chief ends is the providing of amusement. But preparation for this day of pleasure represents months of effort on the part of hundreds and thousands of children and adults, and a great many by-products have resulted which are of priceless value.

Take the schools for instance-that is, those that are fortunate enough to be under the leadership of a good teacher. In getting ready to play their part in the events of the day the pupils become more closely organized, work of all kinds has been better done, school spirit has been developed and physical health has been promoted by participation in games and athletics. The school has become socialized.

Then, too, at the festival the children may measure their accomplishments with those of children from other schools and find out just what are their strong and weak points.

Then later the effect on individual lives. Acquaintances formed on these occasions may be followed up by profitable correspondence, by exchanging visits and thus lead to the establishment of lifelong friendships. The names of those who excel in one sport or another become household words throughout the country. How this stimulates self-respect and ambition! The real leaders in each community become known, be they boys or girls, men or women, and these may be brought together thereafter for organized efforts in worthy enterprises for the common good. And all the time the isolation of country life is being lessened.

Again, how easily may new and desirable features be introduced into a school or a community by these festivals, and what an opportunity they 
afford for getting children to do the old things in the spirit of a new comprehension and from a broader point of view. For instance, if play festivals become a permanent institution in a country and it is known that there will always be competitive athletics and games, then running and jumping, prisoner's base, relay races, and so on, will become permanent features in the physical lives of the children who are within the radius of the festival's influence. If on such days there are events which may be participated in by only boys' clubs, then boys' clubs can thereafter be easily organized and maintained with incalculable benefit throughout the year. If there is to be a competitive exhibit of home-made bread and cake in one of the booths on the festival grounds, then will it be easy to get the girls to give careful attention to the art of baking. If corn-judging or vegetable contest is to be held, then corn patches and home gardens will multiply and flourish. If an exhibit of photographs, programmes, and printed matter showing the operation of men's clubs, women's clubs, Bible study circles, or literary societies should be made, with an intelligent person at hand to answer questions and give explanations, then will such organizations be likely to make their appearance in one community after another throughout the county. If there is to be an exhibit of school work in one of the tents, then all through the year the children will give more attention to the three R's, while sewing, gardening, bench-work, carving, basketry, and art will find a deservedly prominent place in an increasing number of schools and homes.

Perhaps it is not too much to say that through a series of properly conceived and well-conducted festivals the civic and institutional life of an entire country or district, and the lives of many individuals of all ages, may be permanently quickened and inspired, the play movement thus making surely for greater contentment, cleaner morals, and more intense patriotism and righteousness on the farm lands and in the village populations of our country. Such, indeed, are the socializing effects of organized and supervised play. 